\title{
The Importance of Low E-cadherin Expression for Epithelial Mesenchymal Transition (EMT) in Pulmonary Pleomorphic Carcinoma
}

\section{Pulmoner Pleomorfik Karsinomda Epitelyal Mezenkimal Geçiş (EMT) için Düşük E-cadherin Ekspresyonunun Önemi}

\author{
๑ Nurcan Ünver ${ }^{1}, \oplus$ Nur Büyükpınarbaşılı² \\ ${ }^{1}$ Yedikule Chest Diseases and Thoracic Surgery Training and Research Hospital, Clinic of Pathology, İstanbul, Turkey \\ ${ }^{2}$ University of Health Sciences Turkey, Başakşehir Çam ve Sakura State Hospital, Clilnic of Pathology, İstanbul, Turkey
}

Background: Epithelial-mesenchymal transition is an important step in the invasion and metastasis of cancer cells in various cancer types. The aim of this study is to evaluate immunohistochemical staining with E-cadherin in patients with pleomorphic carcinoma (PC), which is a group of advanced lung tumors, to decide the correlation between clinicopathological parameters and to determine the prognostic significance of the results.

Materials and Methods: Materials and data of 56 cases diagnosed with PC between January 2011 and December 2018 were evaluated. Expressions of E-cadherin applied to tumor sections of resection materials were evaluated. Immunohistochemically, data were collected under two groups as low and high according to E-cadherin staining results. The results obtained were compared with clinicopathological findings and prognostic factors.

Results: Forty-five of the fifty-six cases were male (80.36\%) and 11 were female (19.64\%), their age ranged from 44 to 83 years and the average age was 64.12 years. When expressions of E-cadherin were evaluated, loss of expression of E-cadherin (low expression) was observed in 47 (83.9\%) cases. When the disease-free survival time was examined, it was found that the mean time (12 months) in 35 cases was below. No statistically significant correlation was found between the immunohistochemically E-cadherin expressions and other clinicopathological parameters. Our study showed that low E-cadherin expression or loss of E-cadherin expression in spindle and/or giant cell areas has a poor prognostic factor on disease-free survival $(p=0.001)$.

Conclusion: E-cadherin loss has been observed in cases of PC, especially in spindle and/or giant cell areas, and has been associated with shorter disease-free survival. Expression loss of E-cadherin was accepted as a poor prognostic factor. Expression of E-cadherin can be used to evaluate the prognostic potential in PCs with poorly progressive groups.

Keywords: E-cadherin, pulmonary pleomorphic carcinoma, epithelial mesenchymal transition

Amaç: Epitelyal mezankimal geçiş (EMT), çeşitli kanser tiplerinde kanser hücrelerinin istilası ve metastazında önemli bir aşamadır. Bu çalışmanın amacı, ileri akciğer tümörü olan pleomorfik karsinomlu (PC) hastalarda E-kaderin ile immünohistokimyasal boyamayı değerlendirmek, klinikopatolojik parametreler arasındaki korelasyona karar vermek ve sonuçların prognostik önemini belirlemektir. Gereçve Yöntemler: Ocak 2011 -Aralık 2018 tarihleri arasında pleomorfik karsinom tanısı alan 56 olguya ait materyaller ve bu olgulara ait veriler değerlendirildi. Rezeksiyon materyallerine ait tümör kesitlerine uygulanan E-kaderin ekspresyonları değerlendirildi. İmmünohistokimyasal olarak veriler, E-kaderin boyama sonuçlarına göre düşük ve yüksek olmak üzere iki grup altında toplandı. Elde edilen sonuçlar klinikopatolojik bulgularla ve prognostik faktörlerle karşılaştırıldı.

Bulgular: Elli altı olgunun kırk beşi erkek (\%80,36) on biri kadındı (\%19,64),yaşları 44 ila 83 arasında değişmekte olup, yaş ortalaması 64,12 idi. E-kaderin ekspresyonları değerlendirildiğinde 47 (\%83,9) olguda E-kaderin ekspresyon kaybı (düşük ekspresyon) gözlendi. Hastalıksız sağkalım süresi incelendiğinde, 35 olgunun ortalama sürenin (12 ay) altında olduğu bulundu. Immünohistokimyasal olarak E-kaderin ekspresyonları ile diğer klinikopatolojik parametreler arasında istatistiksel olarak anlamlı bir korelasyon saptanmamıştır. Çalışmamız iğsi ve/veya dev hücreli alanlarda düşük E-kaderin ekspresyonunun veya E-kaderin ekspresyon kaybının hastalıksız sağkalım üzerinde kötü bir prognostik faktöre sahip olduğu göstermiştir $(\mathrm{p}=0,001)$.

Sonuç: E-kaderin pleomorfik karsinom olgularında özellikle iğsi ve/veya dev hücreli alanlarda kaybı gözlemlenmiş daha kısa süreli hastalıksız sağkalımla ilintilendirilmiştir. E-kaderin ekspresyon kaybı kötü bir prognostik faktör olarak kabul edilmiştir. E-kaderin ekspresyonu, kötü gidişli tümör grubu olan PC'lerde prognostik potansiyeli değerlendirmek için kullanılabilir.

Anahtar Kelimeler: E-kaderin, pulmoner pleomorfik karsinom, epitelyal mezankimal geçiş

Address for Correspondence: Nurcan Ünver, Yedikule Chest Diseases and Thoracic Surgery Training and Research Hospital, Clinic of Pathology, İstanbul, Turkey Phone: +90 5052160018 E-mail: pat.dr.nurcanunver@gmail.com ORCID ID: orcid.org/0000-0001-7392-6099

Received: 04.02.2021 Accepted: 19.08.2021 


\section{Introduction}

Lung cancer is one of the most common causes of cancer-related deaths in both genders (men and women). Pleomorphic carcinomas (PCs), which are a rare lung cancer, constitute $0.3 \%$ of all lung malignancies (1). In the 2015 World Health Organization's (WHO) classification, PCs are a pulmonary malignancy in which spindle cells and/or giant cell tumor $(\mathrm{T})$ are included together with squamous cell carcinoma, adenocarcinoma or undifferentiated carcinoma. For diagnosis, more than $10 \%$ should be spindle-shaped and/ or giant cells (2). The carcinoma component consisting of spindle or giant cells alone is very rare.

Pulmonary PCs are usually seen in smokers, older males. During diagnosis, it usually causes large-scale, chest wall involvement and distant metastases. The most appropriate form of treatment in PC with poor prognosis is surgery if diagnosed at the appropriate stage. In cases of rare and advanced stage lesions (PC), those who have the chance of operation at the time of diagnosis are extremely rare. The principal of the surgery is anatomic resection and mediastinal lymph node dissections. Even if PC is diagnosed early, 5 years survival rates and mean survival time are very low $(3,4,5)$. In cases where surgery cannot be performed on the PC, the treatment is chemotherapy. In operated cases, if lymph node involvement is present (even N1), adjuvant chemotherapy should be added. Chemotherapy should be applied as combined, not as a single drug.

E-cadherin is a protein component that is effective in cell adhesion, cell-cell interaction, and regulation of other cell functions. E-cadherin has been accepted as an important factor for EMT pathway. On the other hand,EMT is an important step in cancer metastases (6). Loss or absence of expression of E-cadherin was detected immunohistochemically in NSCLC of the lung, demonstrating that this may be associated with the control of cell proliferation in carcinogenesis (7).

E-cadherin is not only a protein that regulates intercellular adhesion, cellular functions, cell differentiation, but also an important $T$ suppressor protein involved in carcinogenesis when there is functional disorder. As determined in the literature, it has been reported that dysregulation of E-cadherin leads to carcinogenesis by obtaining invasive and invasive properties of cells through the EMT pathway (6).

\section{Material and Methods}

Fifty-six cases of pulmonary PC that were surgically resected were involved from February 2011 to December 2018. These 56 patients (45 male and 11 female, age range 44-83 years; mean age 64.13 years) with pulmonary PC underwent surgery with a radical approach (lobectomy and mediastinum lymphadenectomy). Of the $56 \mathrm{PCs}, 32$ had adenocarcinoma component, 15 had squamous cell carcinoma, 9 had large cell carcinoma component.

T stages were defined properly according to the 8.TNM classification of the International Union Against Cancer, (8) and the histological types according to the $2015 \mathrm{WHO}$ classification (2). Demographic data of PC cases and pathological findings such as $T$ diameter, $T$ and lymph node stages, metastasis system, lymphatic, vascular and perineural invasions were collected and expressions of E-cadherin were recorded.

\section{Tissue Immunohistochemistry}

Four micrometer $(4 \mu)$ sections of formalin-fixed paraffinembedded tissues were taken on polylysine-coated slides. Next, the rabbit was stained with polyclonal Biocare Medical E-cadherin antibody (Anti-E-cadherin (36) ouse monoclonal primary antibody according to the manufacturer's protocol). Subsequent procedures were performed with the Ventana BenchMark Ultra (Ventana Medical Systems Inc.) device.

Cytoplasmic and/or membranous staining with E-cadherin antibody was evaluated positively. The estimated percentage of the positively stained T-cells was reported in a scale with four grades: no staining as $0,<10 \%$ as $1,10-50 \%$ as +2 , and $>50 \%$ as +3 . Grouping was performed considering 0 to $1+$ grade as "low" staining and +2 to +3 grade as "high" staining for E-cadherin.

While E-cadherin staining was evaluated by immunohistochemistry, the staining degrees were divided into two categories as "high staining" and "low staining" according to expression levels. E-cadherin expression was compared statistically with clinicopathological data and disease-free survival times.

\section{Statistical Analysis}

Chi-square test was used to evaluate the relationship between clinicopathological parameters and E-cadherin expressions. Survival curves were created using the KaplanMeier method and the data obtained were compared with the log-rank test. Cox regression analysis was performed, $p<0.05$ value was considered statistically significant. All statistical analyses were performed using SPSS 22.0 (Chicago, IL, USA).

\section{Results}

Of the 56 cases, 45 were male (80.36\%) and 11 were female (19.64\%). The ages of the cases ranged between 44 and 83 years. Twelve patients had pneumonectomy, 20 upper right lobectomy, 10 lower left lobectomy, 6 upper left lobectomy, 5 lower right lobectomy, 2 right middle lobectomy and 1 lower right bilobectomy resection. 
T diameters in the resection materials were measured between $1.5 \mathrm{~cm}$ and $11 \mathrm{~cm}$ (average diameter $6.04 \mathrm{~cm}$ ). Pathological T-stages were determined as pT1 in four cases, pT2 in nineteen cases, pT3 in twenty-three cases and pT4 in ten cases. The mean clinical follow-up period was 12 months.

Of the 56 PC, 32 had the adenocarcinoma component, 15 had squamous cell carcinoma (Figure 1a,b,c) and 9 had large cell carcinoma component. Forty-four patients had lymphovascular invasion and 12 patients were not detected.

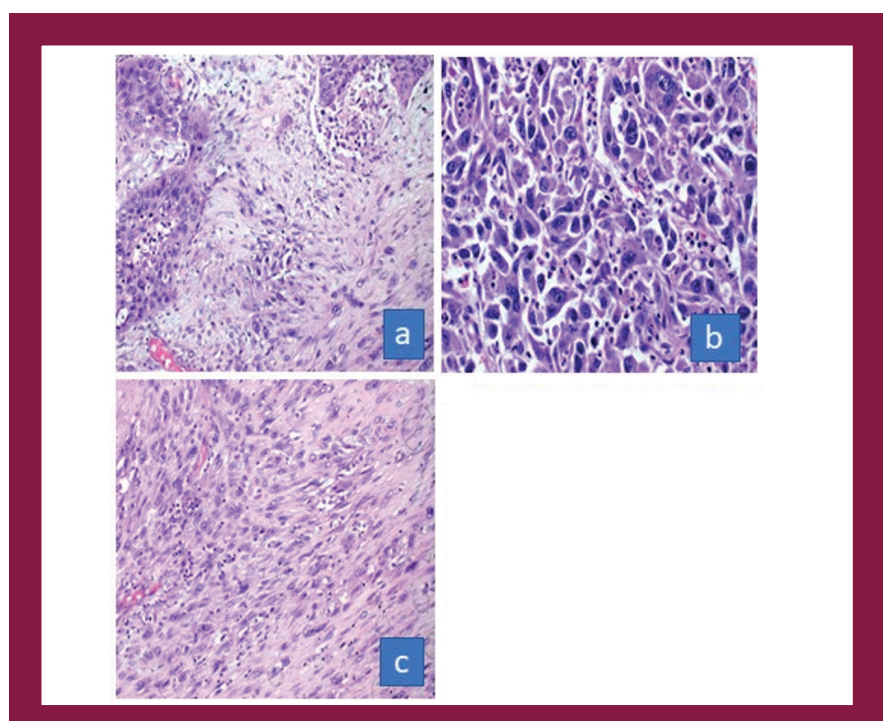

Figure 1. Tissue sections from one of our pleomorphic carcinoma cases containing epithelial and spindle and/or giant cell components. Hematoxylin and eosin staining. Magnification, x400 (a) The epithelial area is accompanied by the presence of squamous cell carcinoma (a) giant cells and (b) spindle cell component (c)

According to the nodal involvement, 33 (58.9\%) of the cases were classified as pN0, 20 patients (35.7\%) as pN1, and 3 patients (5.3\%) as pN2. Twenty-seven patients were perineural invasion and 34 (60.7\%) patients were pleural invasion positive. T necrosis was detected only in two cases. Low level of staining (low expression) with E-cadherin was observed in 47 (83.9\%) of the cases, and in thirty-five of these cases, the mean disease-free survival time was less than 12 months (Figure 2). in the study of the pathological stages of cases, 10 were stage $T 4,19$ were stage $T 3,16$ were stage $T 2$, and 2 were stage T1. When the staining pattern of E-cadherin was evaluated, positive staining was observed in 11 cases (19.6\%) in spindle and/or giant cell carcinoma area, whereas 47 (83.9\%) cases were detected in the epithelial component (Figure 3a,b). Low and non-staining E-cadherin expression in giant cell and/or spindle cell area were detected in all PC cases (Figure 3c,d,e,f).

The low and high staining results of E-cadherin were compared with the clinicopathological data obtained from the patients and presented in a table (Table 1). Statistically,

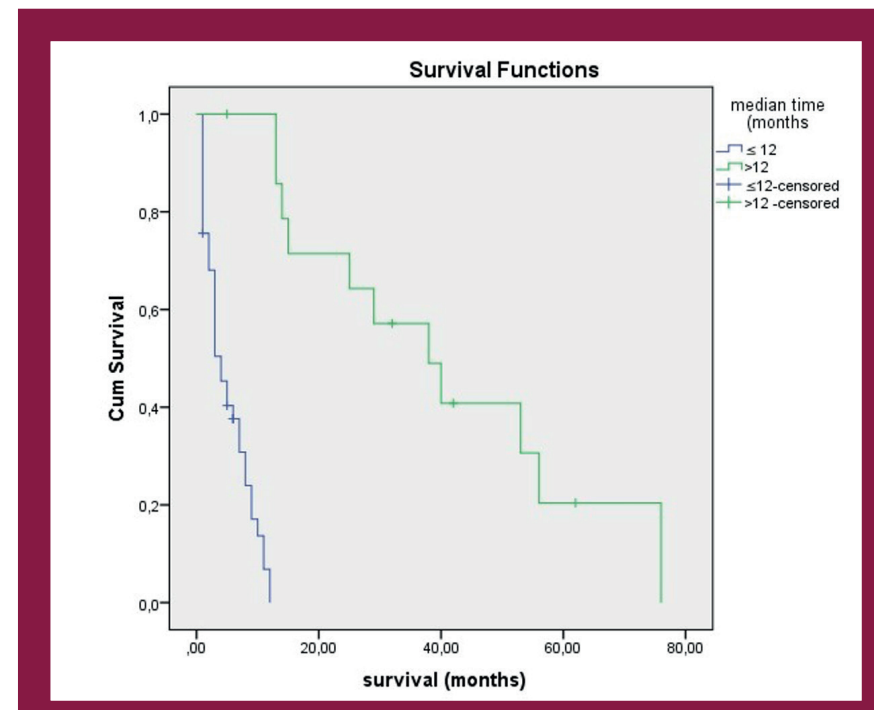

Figure 2. Kaplan-Meier mean disease-free survival time analysis by staining E-cadherin

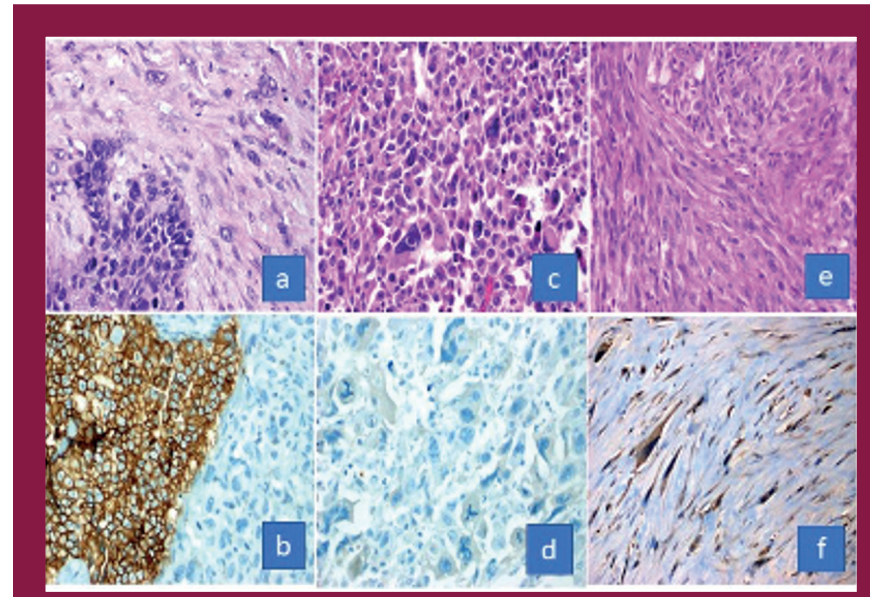

Figure 3. Immunohistochemical examples for Low and High staining of E-cadherin. Magnification, x400. High staining for E-cadherin in in epithelial cell components of PCs, $(a, b)$. No staining was detected for the giant cell component (c,d) low staining for the spindle cell area $(e, f)$

no significant correlation was found between low and high staining patterns of E-cadherin and clinicopathological parameters.

Loss of E-cadherin expression was statistically significantly correlated with spindle and giant cell $T$ area $(p=0.001)$ (Figure 4). No significant correlation was found between loss of expression of $\mathrm{E}$-cadherin in other $\mathrm{T}$ areas.

\section{Discussion}

PC is a very rare histological type of non-small lung cell carcinoma. When diagnosed, there are difficulties in 
Table 1. E-cadherin expression and clinicopathological data of cases (and=56)

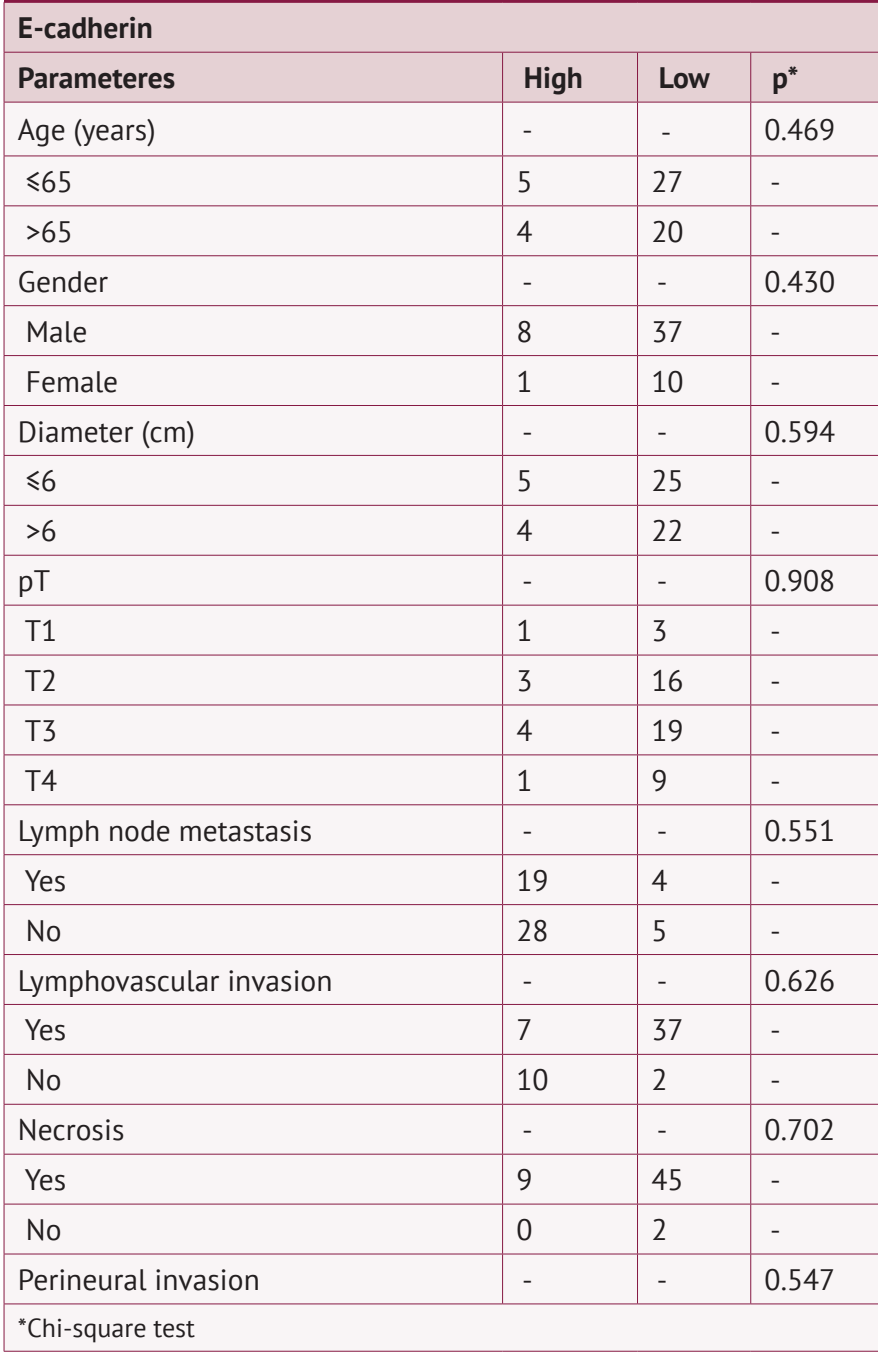

determining the prognostic factors of these advanced and metastatic Ts. We evaluated the PC cases which were immunohistochemically E-cadherin expression loss and/ or negativity. In addition to ongoing research on whether E-cadherin expression loss is the cause or effect of EMT, functional loss of E-cadherin has often been associated with poor prognosis and survival in various cancer types $(7,9,10,11,12,13)$.

In some studies, the staining rate of E-cadherin in lung carcinomas has been documented as $41-78 \%(14,15,16)$. Our study showed that a large proportion (83.9\%) of PC cases lost and or decreased E-cadherin expression.

Our results showed that low E-cadherin expression could be evaluated as a poor prognostic factor among disease-free survival. In similar studies, it has been observed that downregulation of E-cadherin is significantly associated with the stimulation of differentiation from the direction of the $T$ and

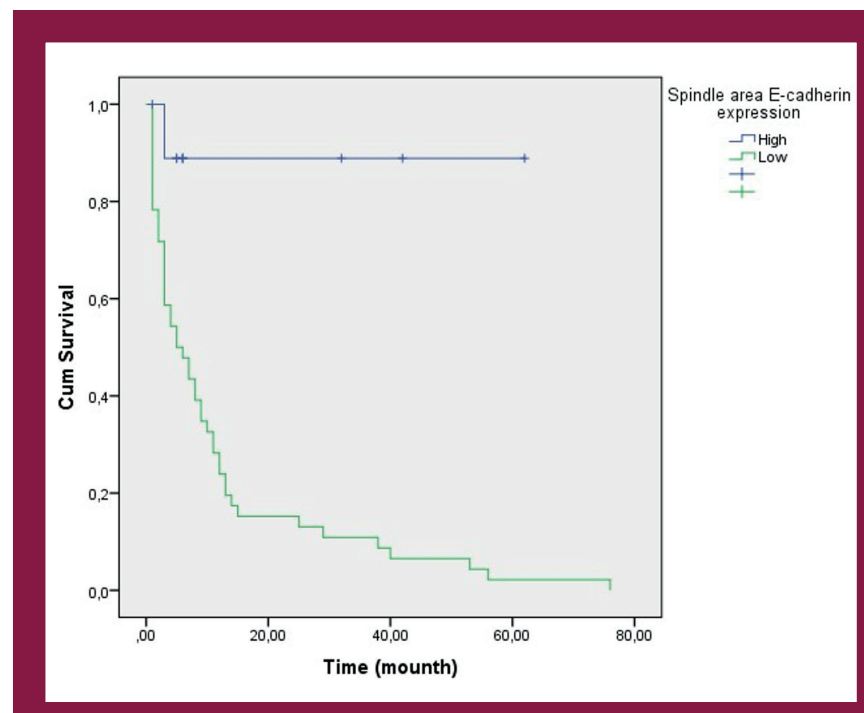

Figure 4. Kaplan-Meier median disease-free survival time analysis by E-cadherin staining pattern in spindle cell area

infiltration (13,14,15). For example, Yang et al. (17) showed that low E-cadherin expression was associated with an increase in lymph node metastasis rate, high grade, vascular invasion, and poor survival. However, our study showed that there was no significant relationship between decreased E-cadherin expression and most parameters such as stage, grade, lymph node involvement, necrosis, and diameter. This can be explained by the small number of PC cases in the subclass of non-small cell carcinoma in our study. Similar results were found in some studies conducted for NSCLC (18).

In our study, a higher E-cadherin staining was detected in the epithelial area of the T, while a reduced in expression was found in the spindle and/or giant cell area. Okimura et al. (19), similar to our study, found a higher rate of staining with E-cadherin in the epithelial area of the $T$ in cases of pulmonary PC.

The loss of expression of E-cadherin in the spindle and giant cell epithelial component in resection materials may explain the invasive potential and increase of their metastases of these Ts.

TKI (Tyrosine Kinase Inhibitors) is frequently used in the treatment of NSCLC and EMT is believed to play an important role in resistance to these drugs $(20,21)$. Some studies have shown that EMT is involved not only in determining the prognosis of patients with NSCLC, but also in response to specific treatments such as anti-EGFR treatments used for this type of T (22). TKI were not used in our cases.

Our results were obtained as a result of a limited number of retrospective studies based on the existing archive screening of our hospital. However, while a relatively small 
number of patients have been analyzed, patient data have been meticulously collected and recorded.

\section{Conclusion}

As shown in studies, loss of expression of E-cadherin has an important role in carcinogenesis and $T$ progression as a result of EMT increase. In different studies made with different types of Ts, it is shown that E-cadherin expression loss is related to poor prognosis. Future studies with different T types may contribute to the development of new therapeutic agents and the determination of prognostic factors.

\section{Ethics}

Ethics Committee Approval: The study design was approved by the appropriate ethic review board Ethics Committee of University of Health Sciences Turkey, İstanbul Training and Research Hospital (approval number and date: 2085/2019; 12/06/2019).

Informed Consent: Informe consent were obtained from all patients before surgery.

Peer-review: Internally peer-reviewed.

\section{Author Contributions}

Surgical and Medical Practices: N.Ü., N.P., Concept: N.Ü., Design: N.Ü., Data Collection or Processing: N.P., Analysis or Interpretation: N.Ü., Literature Search: N.P., Writing: N.Ü.

Conflict of Interest: No conflict of interest was declared by the authors.

Financial Disclosure: The authors declared that this study received no financial support.

\section{References}

1. Ferlay J, Shin HR, Bray F, Forman D, Mathers C, Parkin DM. Estimates of worldwide burden of cancer in 2008: globocan 2008. Int J Cancer. 2010;127:2893-2917. [Crossref]

2. Travis WD, Brambilla E, Burke AP, Marx A, Nicholson AG. World Health Organization Classification of Tumours WHO classification of tumors of the Lung, Pleura, Thymus and Heart. 4th ed. Lyon: IARC Press; 2015. [Crossref]

3. Mochizuki T, Ishii G, Nagai K, Yoshida J, Nishimura M, Mizuno T, et al. Pleomorphic carcinoma of the lung: clinicopathologic characteristics of 70 cases. Am J Surg Pathol. 2008;32:1727-1735. [Crossref]

4. Ji C, Zhong C, Fang W, Zhao H. Surgical treatment for pulmonary pleomorphic carcinoma: A retrospective study of 60 patients. Thorac Cancer. 2014;5:250-254. [Crossref]

5. Okuda K, Oda R, Suzuki A, Sakane T, Kawano O, Haneda H, et al. Clinicopathological factors influenced the prognosis of surgically resected pulmonary pleomorphic carcinoma. J Thorac Dis. 2017;9:12951302. [Crossref]
6. Wong SHM, Fang CM, Chuah LH, Leong CO, Ngai SC. E-cadherin: its dysregulation in carcinogenesis and clinical implications. Crit Rev Oncol Hematol. 2018;121:11-22. [Crossref]

7. Myong NH. Reduced expression of E-cadherin in human non-small cell lung carcinoma. Cancer Res Treat. 2004;36:56-61. [Crossref]

8. Lim W, Ridge CA, Nicholson AG, Mirsadraee S. The 8th lung cancer TNM classification and clinical staging system: review of the changes and clinical implications. Quant Imaging Med Surg. 2018;8:709-718. [Crossref]

9. López-Verdín S, Martínez-Fierro ML, Garza-Veloz I, Zamora-Perez A, Grajeda-Cruz J, González-González R, et al. E-Cadherin gene expression in oral cancer: clinical and prospective data. Med Oral Patol Oral Cir Bucal 2019; 24:e444-e451. doi: 10.4317/medoral.23029. [Crossref]

10. Giannelli G, Koudelkova P, Dituri F, Mikulits W. Role of epithelial to mesenchymal transition in hepatocellular carcinoma. J Hepatol. 2016;65:798-808. [Crossref]

11. Matsubara D, Kishaba Y, Yoshimoto T, Sakuma Y, Sakatani T, Tamura T, et al. Immunohistochemical analysis of the expression of E-cadherin and ZEB1 in non-small cell lung cancer. Pathol Int. 2014;64:560-568. [Crossref]

12. Xu XL, Ling ZQ, Chen SZ, Li B, Ji WH, Mao WM. The impact of E-cadherin expression on the prognosis of esophageal cancer: a meta-analysis. Dis Esophagus. 2014;27:79-86. [Crossref]

13. Tsoukalas N, Aravantinou-Fatorou E, Tolia M, Giaginis C, Galanopoulos M, Kiakou M, et al. Epithelial-mesenchymal transition in non small-cell lung cancer. Anticancer Res. 2017;37:1773-1778. [Crossref]

14. Aruga N, Kijima H, Masuda R, Onozawa H, Yoshizawa T, Tanaka M, et al. Epithelial-mesenchymal Transition (EMT) is Correlated with Patient's Prognosis of Lung Squamous Cell Carcinoma. Tokai J Exp Clin Med. 2018;43:5-13. [Crossref]

15. Grigoraş ML,Arghirescu TS, Folescu R, Talpoş IC, Gîndac CM,Zamfir CL, et al. Expression of E-cadherin in lung carcinoma, other than those with small cells (NSCLC). Rom J Morphol Embryol. 2017;58:1317-1325. [Crossref]

16. Wang G, Ma W, Li Y, Jiang Y, Ma G, Zhang X, et al. Prognostic value of Twist, Snail and E-cadherin expression in pathological NO non-small-cell lung cancer: a retrospective cohort study. Eur J Cardiothorac Surg. 2018;54:237245. [Crossref]

17. Yang YL, Chen MW, Xian L. Prognostic and clinicopathological significance of down regulated $\mathrm{E}$-cadherin expression in patients with non-small cell lung cancer (NSCLC): a meta-analysis. PLoS One. 2014;9:e99763. doi:10.1371/journal.pone.0099763. [Crossref]

18. Lee YC, Wu CT, Chen CS, Chang YL. E-cadherin expression in surgicallyresected non-small cell lung cancers-a clinicopathological study. Thorac Cardiovasc Surg. 2000;48:294-299. [Crossref]

19. Okimura A, Terada N, Hata M, Kawahara K, Iwasaki T, Oota M, et al. Expression of adhesion molecules and transforming growth factor- $\beta$ in pleomorphic carcinomas of the lung. Oncol Lett. 2010;1:959-965. [Crossref]

20. Gkogkou P, Peponi E, Ntaskagiannis D, Murray S, Demou A, Sainis I, et al. E-Cadherin and Syndecan-1 Expression in Patients With Advanced Nonsmall Cell Lung Cancer Treated With Chemoradiotherapy. In Vivo. 2020; 34:453-459. [Crossref]

21. Suda K, Rozeboom L, Rivard CJ, Yu H, Ellison K, Melnick MAC, et al. Therapyinduced E-cadherin down regulation alters expression of programmed death ligand-1 in lung cancer cells. Lung Cancer. 2017;109:1-8. [Crossref]

22. Jakobsen KR, Demuth C, Sorensen BS, Nielsen AL. The role of epithelial to mesenchymal transition in resistance to epidermal growth factor receptor tyrosine kinase inhibitors in non-small cell lung cancer. Transl Lung Cancer Res. 2016;5:172-182. [Crossref] 